\title{
The UTSA Boulevard Project: Archaeological Survey Along Leon Creek in Northwest San Antonio, Texas
}

Herbert G. Uecker

Center for Archaeological Research

Follow this and additional works at: https://scholarworks.sfasu.edu/ita

Part of the American Material Culture Commons, Archaeological Anthropology Commons, Environmental Studies Commons, Other American Studies Commons, Other Arts and Humanities Commons, Other History of Art, Architecture, and Archaeology Commons, and the United States History Commons

Tell us how this article helped you.

This Article is brought to you for free and open access by the Center for Regional Heritage Research at SFA ScholarWorks. It has been accepted for inclusion in Index of Texas Archaeology: Open Access Gray Literature from the Lone Star State by an authorized editor of SFA ScholarWorks. For more information, please contact cdsscholarworks@sfasu.edu. 


\section{The UTSA Boulevard Project: Archaeological Survey Along Leon Creek in Northwest San Antonio, Texas}

\section{Creative Commons License}

\section{(c) (1) \&}

This work is licensed under a Creative Commons Attribution-NonCommercial 4.0 International License 
THE UTSA BOULEVARD PROJECT:

ARCHAEOLOGICAL SURVEY ALONG LEON CREEK IN NORTHWEST

SAN ANTONIO, TEXAS

Herbert G. Uecker

Center for Archaeological Research

The University of Texas at San Antonio

Archaeological Survey Report, No. 216

1992 

THE UTSA BOULEVARD PROJECT:

ARCHAEOLOGICAL SURVEY ALONG LEON CREEK IN NORTHWEST

SAN ANTONIO, TEXAS

Herbert G. Uecker

Center for Archaeological Research The University of Texas at San Antonio ${ }^{\circledR}$ Archaeological Survey Report, No. 216 



\begin{abstract}
A tract of land in northern San Antonio was briefly examined by the Center for Archaeological Research (CAR), The University of Texas at San Antonio (UTSA). Several prehistoric archaeological sites had previously been recorded and test excavated within or near the property. Remnants of two of those sites (41 BX 47 and $41 \mathrm{BX}$ 231) within the study area were rediscovered and subjected to limited subsurface testing. At $41 \mathrm{BX} 231$, what are apparently well-preserved prehistoric cultural deposits were identified. Thus, it is recommended that additional intensive excavations be performed prior to any future disturbances at that site, or that alteration of the site and immediate vicinity be avoided. Site $41 \mathrm{BX} 47$ was found to no longer be intact and no further work there is required. For various reasons, but most notably because heavy ground cover prevented a clear view of the surface, it is also recommended that all future activities on the property be archaeologically monitored.
\end{abstract}




\section{TABLE OF CONTENTS}

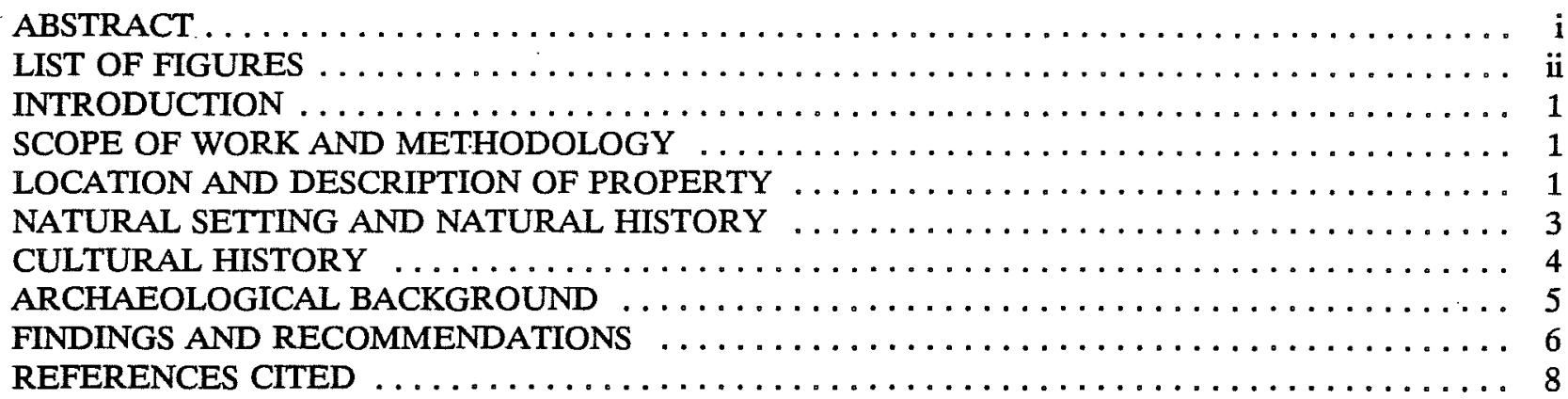

\section{LIST OF FIGURES}

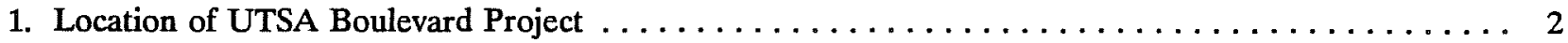

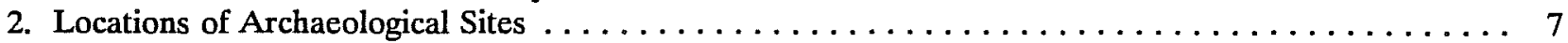




\section{INTRODUCTION}

Pursuant to the terms of an agreement with Pape-Dawson Engineers of San Antonio, a tract of land (approximately 24.28 hectares or 60 acres; Fig. 1) in northern San Antonio was briefly investigated by the CARUTSA. At the time of the examination the land was privately owned; however, the proposed immanent development of the property and its proximity to the Leon Creek channel warranted the performance of a cultural resource survey prior to construction work. By contract provision, the ownership of the property and the nature of the proposed improvements are not disclosed. Jack D. Eaton, acting director of the CAR-UTSA, was principal investigator for the project. Herbert G. Uecker, staff archaeologist, was co-principal investigator and directed the field work and report preparation. Uecker was assisted in the field by Kevin Gross and Cynthia Tennis.

\section{SCOPE OF WORK AND METHODOLOGY}

Cultural resource surveys of the kind performed for the UTSA Boulevard Project are usually comprised of at least two major elements: (1) a comprehensive background check including searches of the files of appropriate research institutions and libraries, examination of historical and archival references pertinent to the general region and to the specific area under study; and (2) an intensive pedestrian reconnaissance, including subsurface investigations of promising areas by hand excavations of small test holes. For the UTSA Boulevard Project, the records of the CAR-UTSA and Texas Archeological Research Laboratory (TARL), The University of Texas at Austin (UT) were searched on September 21 and 22, 1992. Additional background research at the CAR-UTSA was continued throughout the project time-frame by Uecker. Uecker and Gross performed most of the on-site examination of the property on September 25, 28, and 30, and Uecker and Tennis completed that phase of the work on October 5, 1992.

The latter included a walk over the property and the digging of 14 shovel tests at two prehistoric archaeological sites. The pedestrian discourse was hampered by the presence of dense natural groundcovers and undergrowth. Since the area had been subjected to trash dumping for several decades, there was also an abundance of artificial debris present. Surface visibility is estimated to have ranged between only about $5 \%-10 \%$ over most of the property.

All of the test excavations were about $30 \mathrm{~cm}$ in diameter and about $40-50 \mathrm{~cm}$ deep. Matrix was screened using one-quarter-inch mesh hardware cloth, and all visible artifacts were collected from the screened fraction and delivered to the CAR-UTSA Archaeology Laboratory. There they will be cleaned, labelled, and permanently curated. Due to the limited scope and budget of the project, no detailed analysis of the artifacts was performed. Soil matrix samples were obtained from several areas tested.

\section{LOCATION AND DESCRIPTION OF PROPERTY}

The area investigated is located in the northwest portion of the city of San Antonio, approximately $3 \mathrm{~km}$ west of the crossing of UTSA Boulevard and Interstate Highway 10 (Robert F. McDermott Freeway). It is immediately south of the UTSA campus and its northeast corner is near the intersection of UTSA and Regency Boulevards. It is roughly trapezoidal shaped and the northern boundary follows the south side of UTSA Boulevard westward from the Regency-UTSA Boulevard junction to the intersection of James Bauerle and UTSA Boulevards, a distance of about $520 \mathrm{~m}$.

The east boundary line of the property extends almost due south from the Regency-UTSA Boulevard intersection a distance of roughly $425 \mathrm{~m}$. The south boundary line of the property extends about $800 \mathrm{~m}$ east to west from the south end of the east boundary line. Although the west boundary line doglegs at several points, it extends approximately $490 \mathrm{~m}$ on a general trend (from the west end of the southern boundary) of about $45^{\circ}$ (clockwise from north). 


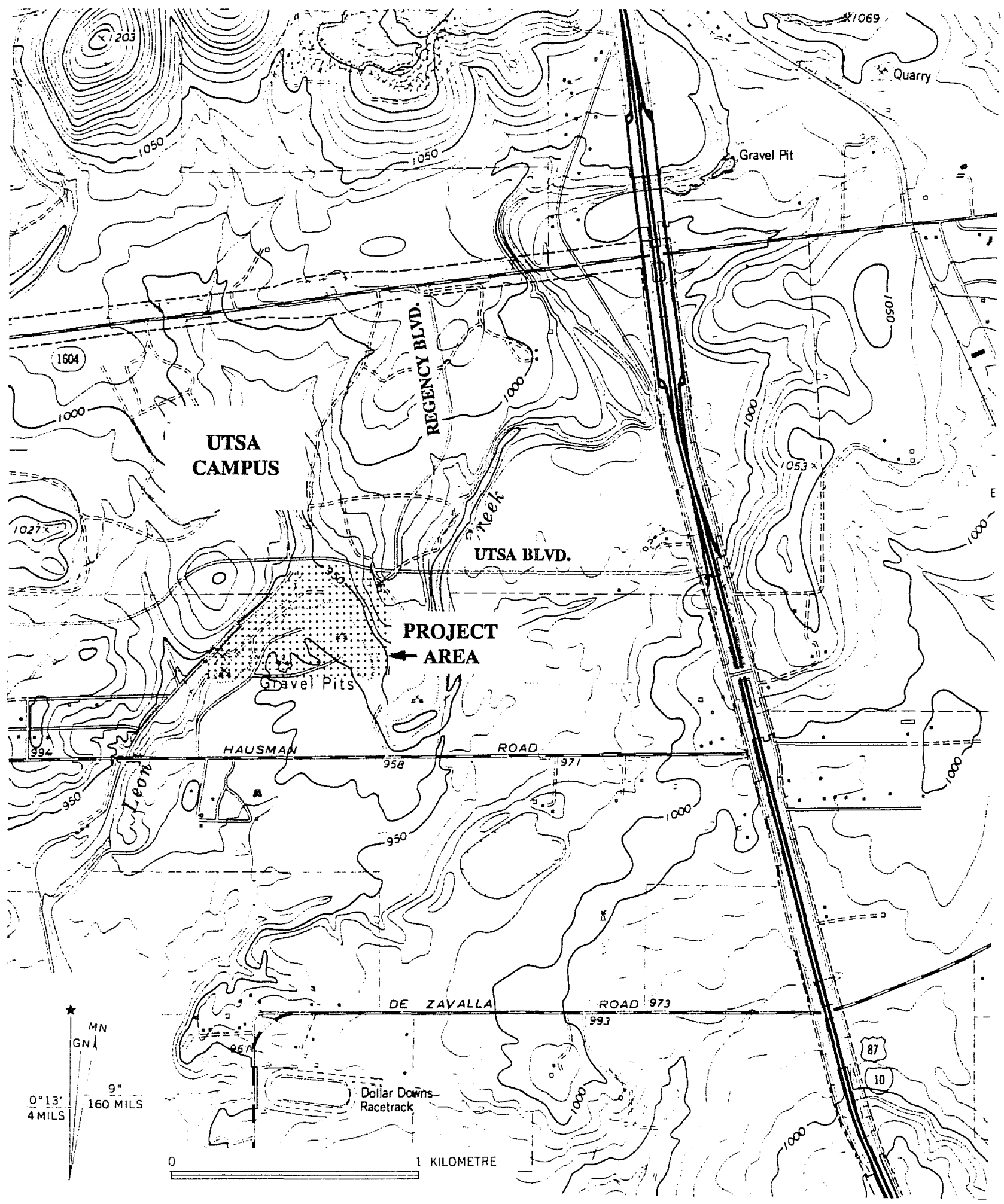

Figure 1. Location of the UTSA Boulevard Project. 
The tract encompasses a segment of the Leon Creek channel that is roughly bow-shaped and about $1 \mathrm{~km}$ in length. The two ends of the segment are located near the southeast and southwest corners of the property and the apex of the bow is about $180 \mathrm{~m}$ southeast of the James Bauerle-UTSA Boulevard intersection near the north boundary line. The western arm of the bow has been dammed at the south end, forming what is known locally as Delavin Lake (named after Mr. George W. Delavin, a former owner of the adjacent property). Although Leon Creek was generally ephemeral and was not flowing at the time of the CAR-UTSA study, there was a sizeable body (approximately $600 \mathrm{~m}$ long, $60 \mathrm{~m}$ average width, with estimated depth of about $2-4 \mathrm{~m}$ ) of water in the lake.

On the north side of the channel segment a relatively steep bluff rises some $15 \mathrm{~m}$ above the floodplain area to the south of the channel, dividing the property into two distinct topographic and biotic zones. The lower area has been mined fairly extensively in modern times for gravel and backfilled as a landfill, leaving virtually no portion undisturbed. Vegetational patterns in the latter zone are clearly the result of secondary succession incurred by repeated disruption of the ground surface during recent decades. The upper portion of the property between UTSA Boulevard and Leon Creek was in a comparatively well-preserved natural condition and exhibited what was probably a climax vegetational pattern for the general area.

\section{NATURAL SETTING AND NATURAL HISTORY}

The regional physiographic and geologic setting of the property has been described in detail at several points in the extant literature (cf. Mahula 1976:2-6;Black and McGraw 1985:40-54;Abbott and Woodruff, eds. 1986;Black 1989a:5-16). Briefly, the property is located at an elevation of about $300 \mathrm{~m}$ asl amidst the Balcones fault zone at the southern edge of the Balcones Escarpment in central Texas. This area is also known as the Balcones Canyonlands. Faulting began in the area during the Miocene geologic epoch about 21 million years (m.y.) ago and continued intermittently until about one m.y. ago.

The local geomorphology is comprised of a series of northeast to southwest trending fault scarps and associated erosional features. Major drainages in the area include the Medina River to the west and southwest, the San Antonio River to the southeast, and the Guadalupe River to the north. Also, several prominent streams dissect the area. These include Salado Creek, that trends north-south about $10 \mathrm{~km}$ east of the property; Leon Creek, that also trends generally north-south and passes through the property; and Cibolo Creek, that trends roughly east-west along the Bexar/Comal County line about $30 \mathrm{~km}$ to the north. The regional drainage pattern is dendritic and the topography is the characteristic rolling terrain of the Texas Hill Country.

Base or parent rocks of the area include several members of the Lower Cretaceous series including the Del Rio shale formation and the Buda, Edwards, and Glenrose limestones. Although these formations collectively range up to as much as ten thousand $\mathrm{m}$ thick over much of central and south Texas, together they are about $450 \mathrm{~m}$ thick in the general vicinity of the property. They were formed during the Cretaceous geologic period between about 120 and 65 m.y. before present (B. P.)*. Outcrops of both the Del Rio Shale and the Buda limestone were identified on the property by the CAR-UTSA field team.

Numerous karst features have formed over the last several m.y. within the limestone formations, which also house the Edwards aquifer. The aquifer is a regional-scale phenomenon composed of porous beds of limestone and shale sandwiched between less permeable calcareous strata and it is virtually the sole source of potable ground water for the city of San Antonio and much of central Texas. Soils in the area are generally of the TerrantBrackett association (United States Department of Agriculture 1966). They are derivatives of the local bedrock and are very thin, stony, and underdeveloped in the uplands. On the portion of the property that includes the banks and low terraces of Leon Creek, soils range up to several $m$ in depth and are capped with a relatively thick humus layer.

*B.P. refers to before 1950. 
Ecologically, the area has been a resource-refugium zone since the middle of the Holocene geologic epoch about 7000 B. P. It was at that juncture in time that the onset of the Altithermal climatic episode (Nance 1972) began to seriously alter the climate of the North American southwest, including Texas. The Altithermal was a period of relatively intense heating and drying that lasted, with only a few short breaks, until the present time. As the lush tall-grass steppes and mixed-grass prairies of south and west Texas were reduced to thorn scrublands and semiarid deserts over several millennia, both animal and human populations gradually congregated in such areas as the Rio Grande basin and the mountain forests of west Texas and northern Mexico, and also in the central Texas Hill Country north of San Antonio.

The Balcones Escarpment falls within an ecotonal zone that exhibits characteristics of three major natural regions (cf. Blair 1950;Riskind and Diamond 1988): (1) the Balconian Biotic Province, a subtropical, subhumid mixed woodland or parkland that is geographically congruent with much of the Texas Hill Country and is dominated by juniper-oak scrub forests; (2) the Tamaulipan Biotic Province, a subtropical to megathermal desert steppe or thorn scrubland that ranges southward from San Antonio into the coastal and Rio Grande plains and well into northern Mexico that is mostly dominated by huisache and mesquite; and (3) the Blackland Prairie, a subtropical, subhumid area characterized by mixed savannah grassland or prairie and postoak/blackjack oak woodlands that ranges northward and eastward to the Red River area near the Texas-Oklahoma border. Modern annual precipitation in the San Antonio-Bexar County area averages about 700-800 $\mathrm{mm}$ and follows a bimodal pattern with maxima in May and September. The Balcones tablelands have sometimes been the locus of world record precipitation events triggered by tropical waves of warm moist air from the Gulf of Mexico colliding with colder dryer air of arctic and subarctic origins surging southward from the high plains regions (Caran and Baker 1986).

In the early 1990s, there were hundreds or even thousands of species of plants, animals, and insects thriving in the Balcones Escarpment and Canyonlands regions. It is beyond the scope of this report to include a comprehensive listing of these species. Major terrestrial faunal species and avifaunal species of the area include the while-tailed deer, javalina, coyote, red fox, opossum, raccoon, ringtailed cat, squirrel, striped skunk, armadillo, wild turkey, bobwhite quail, Inca dove, white-winged dove, box tortoise, and western diamondback rattlesnake. Prominent raptors include turkey and black vultures and various species of owls perennially; and red-tailed hawks, eagles and peregrine falcons seasonally. Also, cougar and bobcat are occasionally seen in northern Bexar County and in the less populated areas of surrounding counties.

Major plant species and habitats observed on the property by the CAR-UTSA field team are typical of those found throughout the region. Live oak up to nearly $20 \mathrm{~m}$ in height and large mountain laurel, persimmon, and juniper trees dominated the uppermost elevations of the property close to UTSA Boulevard. There also were a few Spanish dagger, softleaf yucca, and sotol plants present. The lower elevations to the south of the Leon Creek channel were covered mostly in scrub hackberry and persimmon, whitebrush, giant ragweed, cockle burrs, snow-on-the-prairie, narrow leafed yuccas, and numerous short and mid grasses. The terrestrial margins of the Leon Creek channel supported many cedar-elm and other deciduous trees, vines, and herbaceous plants.

\section{CULTURAL HISTORY}

Probably attracted by the abundance of pristine surface water and the steep ecological gradients and rich microenvironments present, humans first occupied the project area at least 11,000 years B. P. The local cultural history contains four broad divisions (cf. Hester 1980:27-3; Black and McGraw 1985:35-40): (1) the Paleoindian period (ca. 11,000-8000 B. P.), (2) the Archaic period (ca. 8000-1500 B. P.), the Late Prehistoric period (ca. 1500464 B. P.), and the Historic period (ca. 464 years B. P. to present). During all but the Historic period, humans in the area were engaged in a nomadic to semisedentary hunting and gathering lifeway. The Historic period in Texas began in the early 16th century (ca. 1528-1536) as the Spanish explorer Alvar Núñez Cabeza de Vaca and a small party of companions passed through the coastal plains region on his six-year odyssey from the west coast of Florida to Mexico City. 
During the period from roughly the second decade of the 16 th century to the terminal 17 th century, the Spanish colonized all of what is now Mexico to the Rio Grande. In the last decade of the 17th century, several Spanish expeditions penetrated north of the Rio Grande to the vicinity of what is now San Antonio. The settlement of San Antonio de Padua (later renamed San Antonio de Bexar) officially began in about 1718 with the building of the first Spanish colonial Catholic mission and presidio along the banks of the San Antonio River at a location near what is now San Pedro Park. In 1731, a party of Canary Islanders arrived from Spain to join the fledgling colony of priests, soldiers, and mission Indians. The metropolis of San Antonio, with its 800,000+ inhabitants, has grown from the these early 18 th century beginnings.

The project scope did not include a comprehensive investigation of land use during the Historic period. William Woller (a long-time local resident whose family members occupied various tracts of land near the project area since late 19th to early 20th centuries) was informally interviewed by Uecker. Woller was not aware of any historic structures that ever existed on the property (William Woller personal communication 1992), nor was evidence for the latter discovered during the CAR-UTSA and TARL-UT file searches. Nevertheless, due to poor ground surface visibility during the CAR-UTSA foot survey, it was not possible to determine with certainty that no remnants of historic structures existed on the property.

The proximity of a major camino real or royal road (now Interstate Highway 10) used during the Spanish Colonial period has greatly influenced the character of Historic-period human settlement and development in the vicinity. Prior to its use by the Spanish, the road was used by numerous Indian groups, both indigenous and foreign. Its juncture with the San Pedro Creek near San Antonio de Padua was known during the 18th and 19th centuries as the Pasito de los Apaches, or pass of the Apaches, who invaded Texas and Bexar County from the southern high plains region. As a major route from the Balcones Escarpment and Canyonlands to the Coastal Plains resource zones, the corridor was probably much used during prehistory as well.

After the establishment of the German communities of Boerne and Fredericksburg northwest of San Antonio during the mid 19th century, the road was used first by mule-team freighters and later became a postal and stage line (Thonhoff 1971;Uecker 1991). As a modern highway, today it is one of several major arteries that facilitate travel and trucking between central and west Texas, San Antonio, and the coastal cities to the south and east. Just as in times past, it is still attracting people and their institutions to the northwest portion of San Antonio. Some of the most prominent developments to occur in the Interstate Highway 10 growth corridor during the last few decades include the University of Texas at San Antonio main campus, the mixed-use La Cantera development, and the Fiesta Texas entertainment and ethnocultural theme park.

\section{ARCHAEOLOGICAL BACKGROUND}

The archaeological backgrounds of central Texas and Bexar County are too extensive to summarize adequately in this report and the interested reader is referred to Hester (1980); Black and McGraw (1985), and Black (1989b) for further information. Avocational and professional archaeologists have been active in Bexar County since at least the 1930s, and at this writing there were about 985 archaeological sites in the county that were on record at the TARL-UT. Most of those sites are locations of prehistoric Indian activities (seasonal base camps or short-term special use areas), but many Historic-period sites have also been documented and investigated scientifically in the county. All recorded sites are designated in the archaeological literature by a standard trinomial alphanumerical system. For example, the Alamo mission is designated as $41 \mathrm{BX} 6$, wherein 41 is the number for Texas (It is the forty-first state in an alphabetical list of all states in the United States.), BX is the abbreviation for Bexar County, and 6 is the number reflecting that the mission was the sixth site recorded in Bexar County during the history of record keeping. 
Several archaeological investigations have occurred and numerous prehistoric Indian sites have been discovered and recorded in the immediate vicinity of the project property. Briefly, the previous work was performed during: (1) a survey of Leon Creek by avocational archaeologists in the early 1970s; (2) excavations at 41 BX 52 (located near the intersection of Charles W. Anderson Loop 1604 and Interstate Highway 10 a few km northeast of the project property) conducted by the Texas Department of Highways and Public Transportation during the 1970s and 1980s; (3) and class project-related surveys of the UTSA campus and excavations at 41 BX 72 and 41 BX 231 directed by Thomas R. Hester and Joel Gunn (then professors of anthropology at UTSA) during the mid 1970s and in 1986 (cf. Gunn n. d.,1976; Hester n. d.;Huebner 1986;Scott 1986a,1986b;Troutman and Karbula 1986). These investigations encountered remnants of prehistoric Indian cultures dating from the Paleoindian through the Late Prehistoric cultural periods. In several of these cases, the sites tested were found to contain fairly extensive and well-preserved cultural deposits that were archaeologically significant.

From maps on file, all or portions of at least five sites appear to be located within the project boundary as shown

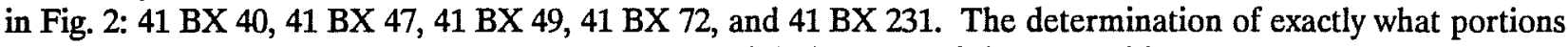
of which sites are within the boundary was not possible because of three conditions extant at the time of the project: (1) maps showing the precise locations of these sites with relation to existing landmarks and topography were not present in the official site files and were not able to be located elsewhere, (2) the property was too overgrown to examine according to standard archaeological survey procedures, and (3) the property boundary was not marked on the ground. Thus, the locations of sites as shown and outlined herein are estimations only.

\section{FINDINGS AND RECOMMENDATIONS}

Two prehistoric Indian sites were relocated and test excavated (small shovel tests only) during the investigations: 41 BX 47 and 41 BX 231. Site 41 BX 47 was first found and recorded in about 1972 by William B. Fawcett, Jr. and Paul R. McGuff during an archaeological survey of the Leon Creek drainage. It was located on a gravel bar at the margin of an old channel of Leon Creek in the lower (southern) portion of the property, and the few remaining cultural deposits found by the CAR-UTSA investigators appeared to have been radically disturbed and deflated by periodic flooding. An ephemeral scatter of burned limestone fragments and chert chipping debris extending over a small area (about $30 \mathrm{~m}$ in diameter) were the only vestiges of the site visible on the surface and shovel tests were largely negative. No intact cultural stratigraphy was encountered. Based on results of the test excavations and intensive surface examinations, no further work is recommended at site 41 BX 47 .

Site 41 BX 231 was first discovered and recorded during the UTSA campus survey of the mid

1970s. It is apparently located at the extreme northwestern corner of the project property near the intersection of James Bauerle and UTSA Boulevards. It was test excavated by several UTSA students under the direction of Joel Gunn in 1975 and found to contain well-preserved cultural strata and distinguishable intrasite activity areas (including a clearly defined burned rock midden component) dating from the middle Archaic through the Late Prehistoric periods.

The CAR-UTSA investigators found sizeable remnants of the site, some of which had been badly looted since the Gunn excavation. Shovel tests and intensive surface examination revealed that the remaining prehistoric cultural deposits extended over an area about 40-60 m in diameter (as far as could be determined given the thick vegetational cover and the time available for shovel testing). In some shovel tests the deposits seemed to be well-preserved and consisted of dense, tightly-packed burned limestone fragments mixed with chert chipping debris, charcoal fragments and ashy soil, land snail shells, and burned and unburned animal bone of considerable antiquity that continued to depths of $50+\mathrm{cm}$ in several cases. A Pedernales dart point fragment was the only time-diagnostic artifact found at the site, and it was found in a surface context. Information is sketchy, but apparently many time-diagnostic artifacts dating from the early or middle Archaic through the Late Prehistoric period were taken from this site by looters over the course of several decades of random digging and surface collecting (Thomas R. Hester personal communication 1992). 
This page has been

redacted because it

contains restricted

information. 
Even though a substantial portion of the site has been destroyed by modern looters, the remainder of the site appears to contain preserved burned rock midden deposits that could be of archaeological significance. Thus, prior to any further artificial disturbance, intensive subsurface testing (backhoe and hand excavations) should be conducted at the site to better determine its extent and degree of preservation, its potential for designation as a Texas Historical Landmark, and its eligibility for listing in the National Register of Historic Places. Also, because the aforementioned conditions prevented the performance of a reasonably accurate archaeological field investigation, it is also recommended that all future construction work (including but not limited to land clearing operations) on the project property be archaeologically monitored.

\section{REFERENCES CITED}

Abbott, P. L. and C. M. Woodruff, Jr., eds.

1986 The Balcones Escarpment: Geology, Hydrology, Ecology and Social Development in Central Texas. Printed for the November 1986 Geological Society of America Annual Meeting in San Antonio, Texas by Comet Reproduction Service, Santa Fe Springs, California.

Black, S. L.

1989a Environmental Setting. In: From the Gulf Coast to the Rio Grande: Human Adaptation in Central, South, and Lower Pecos Texas by Thomas R. Hester, Stephen L. Black, D. Gentry Steele, Ben W. Olive, Anne A. Fox, Karl J. Reinhard, and Leland C. Bement, pp. 5-16. Arkansas Archeological Survey Research Series 33. Final Report Submitted to the U. S. Army Corps of Engineers, Southwestern Division. Study Unit 3 of the Southwestern Division Archeological Overview. Prepared by the Center for Archaeological Research at the University of Texas at San Antonio, Texas A \& M University, and the Arkansas Archeological Survey. Printed by the Arkansas Department of Corrections, Wrightsville, Arkansas.

1989b South Texas Plains. In: From the Gulf Coast to the Rio Grande: Human Adaptation in Central, South, and Lower Pecos Texas by Thomas R. Hester, Stephen L. Black, D. Gentry Steele, Ben W. Olive, Anne A. Fox, Karl J. Reinhard, and Leland C. Bement, pp. 39-62. Arkansas Archeological Survey Research Series 33. Final Report Submitted to the U. S. Army Corps of Engineers, Southwestern Division. Study Unit 3 of the Southwestern Division Archeological Overview. Prepared by the Center for Archaeological Research at the University of Texas at San Antonio, Texas A\&M University, and the Arkansas Archeological Survey. Printed by the Arkansas Department of Corrections, Wrightsville, Arkansas.

Black, S. L. and A. J. Mcgraw

1985 The Panther Springs Creek Site: Cultural Change and Continuity within the Upper Salado Creek Watershed, South-Central Texas. Center for Archaeological Research, The University of Texas at San Antonio, Archaeological Survey Report 100.

Blair, W. F.

1950 The Biotic Provinces of Texas. Texas Journal of Science, 2:104. 
Caran, S. C. and V. R. Baker

1986 Flooding Along the Balcones Escarpment, Central Texas. In: The Balcones Escarpment: Geology, Hydrology, Ecology, and Social Development in Central Texas, edited by P. L. Abbott and C. M. Woodruff, Jr, pp. 1-14. Published for the Geological Society of America Annual Meeting, San Antonio, Texas, November, 1986. Printed by Comet Reproduction Service, Santa Fe Springs, California.

Gunn, J.

1976 The Regency Site: A Preliminary Report on Excavation and Analysis of a Burned Rock Midden in South Central Texas. Ms. on file at the Center for Archaeological Research, The University of Texas at San Antonio.

n. d. The Campus Project. Ms. on file at the Center for Archaeological Research, The University of Texas at San Antonio.

Hester, T. R.

1980 Digging into South Texas Prehistory, A Guide for Amateur Archaeologists. Corona Publishing Company, San Antonio.

n. d. An Archaeological Reconnaissance of the University of Texas at San Antonio Campus. Ms. on file at the Center for Archaeological Research, The University of Texas at San Antonio.

Huebner, J. A.

1986 Archaeological Testing at the Callisto Site (41 BX 72): Preliminary Report (Partial). Ms. on file at the Center for Archaeological Research, The University of Texas at San Antonio.

Mahula, R. A.

1976 Site 41 BX 232: An Ecological Evaluation. In: The Regency Site: A Preliminary Report on Excavation and Analysis of a Burned Rock Midden in South Central Texas, edited by Joel Gunn, pp. 2-6. Ms. on file at the Center for Archaeological Research, The University of Texas at San Antonio.

Nance, C. R.

1972 Cultural Evidence for the Altithermal in Texas and Mexico. Southwestern Journal of Anthropology 28:169-192.

Riskind, D. H., and D. D. Diamond

1988 An Introduction to Environments and Vegetation. In: Edwards Plateau Vegetation: Plant Ecological Studies in Central Texas edited by B. B. Amos and F. R. Gehlbach, pp. 1-15. Baylor University Press, Waco, Texas. 
Scott, $\mathrm{K}$.

1986a Methodology and Previous Research at 41 BX 72: The Callisto Site. Ms. on file at the Center for Archaeological Research, The University of Texas at San Antonio.

1986b Recent Research at Site 41 BX 72. Friends of Archaeology 3:20-22.

Thonhoff, R. H.

1971 San Antonio Stage Lines 1847-1881. Texas Western Press. The University of Texas at El Paso. Southwestern Studies Monograph 29.

Troutman, B. and Karbula, J.

1986 Lithic Analysis for 41 BX 72: Preliminary Report. Ms. on file at the Center for Archaeological Research, The University of Texas at San Antonio.

Uecker, H. G.

1991 Archival and Historical Research for the San Pedro Creek Channel Improvement Project: The 1989-1990 Investigations. Center for Archaeological Research, The University of Texas at San Antonio, Archaeological Survey Report 199.

United States Department of Agriculture

1966 Soil Survey of Bexar County, Texas. 